\title{
Supervisory control of an anaerobic digester subject to drastic substrate changes
}

\author{
Ghofrani Isfahani, Parisa; Valverde Pérez, Borja; Alvarado-Morales, Merlin; Shahrokhi, Mohammad; \\ Vossoughi, Manouchehr; Angelidaki, Irini
}

\section{Published in:}

Chemical Engineering Journal

Link to article, DOI:

10.1016/j.cej.2019.123502

Publication date:

2020

Document Version

Peer reviewed version

Link back to DTU Orbit

Citation (APA):

Ghofrani Isfahani, P., Valverde Pérez, B., Alvarado-Morales, M., Shahrokhi, M., Vossoughi, M., \& Angelidaki, I. (2020). Supervisory control of an anaerobic digester subject to drastic substrate changes. Chemical Engineering Journal, 391, [123502]. https://doi.org/10.1016/j.cej.2019.123502

\section{General rights}

Copyright and moral rights for the publications made accessible in the public portal are retained by the authors and/or other copyright owners and it is a condition of accessing publications that users recognise and abide by the legal requirements associated with these rights.

- Users may download and print one copy of any publication from the public portal for the purpose of private study or research.

- You may not further distribute the material or use it for any profit-making activity or commercial gain

- You may freely distribute the URL identifying the publication in the public portal 


\section{Supervisory control of an anaerobic digester subject to drastic substrate changes}

Parisa Ghofrani-Isfahani ${ }^{\mathrm{a}, \mathrm{b}}$, Borja Valverde-Pérez ${ }^{\mathrm{a}}$, Merlin Alvarado-Morales ${ }^{\mathrm{a}}$, Mohammad Shahrokhi ${ }^{\mathrm{b}, *}$, Manouchehr Vossoughi ${ }^{\mathrm{b}}$, Irini Angelidaki ${ }^{\mathrm{a}, *}$

a Department of Environmental Engineering, Technical University of Denmark, Kgs. Lyngby, DK-2800, Denmark

${ }^{\mathrm{b}}$ Department of Chemical and Petroleum Engineering, Sharif University of Technology, P.O. Box 11365-9465, Azadi Ave., Tehran, Iran

${ }^{*}$ Corresponding authors:

Irini Angelidaki

Department of Environmental Engineering, Technical University of Denmark,

Bld 115, 2800 Lyngby Denmark

E-mail: iria@env.dtu.dk,

Tel.: +4545251429 ; fax: +4545932850

Mohammad Shahrokhi

Department of Chemical and Petroleum Engineering, Sharif University of Technology, P.O. Box 11365-9465, Azadi Ave., Tehran, Iran

E-mail: shahrokhi@sharif.edu

Tel: +982166165419 


\begin{abstract}
Anaerobic digestion (AD) is a green technology that has been applied for many years. One of the main problems in this process is controlling these bioreactors to maximize methane production. A supervisory control strategy has been proposed to improve the methane production rate in an anaerobic digestion process while minimizing the risk of process failure in the presence of several drastic feedstock changes. The inner loop consisted of a feedback control that manipulated the feed flow rate for achieving the desirable methane production rate. A rule based control strategy was used as supervisory control loop. This controller received the total volatile fatty acids concentration in the reactor and the trends of methane production rate to calculate the set-point of the inner control loop. $\mathrm{pH}$ was used as a safety control parameter to prevent the system from acidification. The proposed control scheme was tested in the presence of several disturbances in the feedstock, including glucose overload, ammonia inhibition, substrate dilution and shifting feeding from manure to bio-pulp. The controller prevented VFA accumulation above $2.73,2.94$ and $4.09 \mathrm{~g} \mathrm{~L}^{-1}$, under glucose overload, ammonia inhibition and change of feedstock to bio-pulp, respectively. Thus, the supervisory control could successfully improve the methane production rate and keep the reactor stable against external severe disturbances.
\end{abstract}

\title{
Keywords
}

Process control; Supervisory control; Anaerobic digestion; Biogas production; Bioreactor failure; Volatile fatty acids 


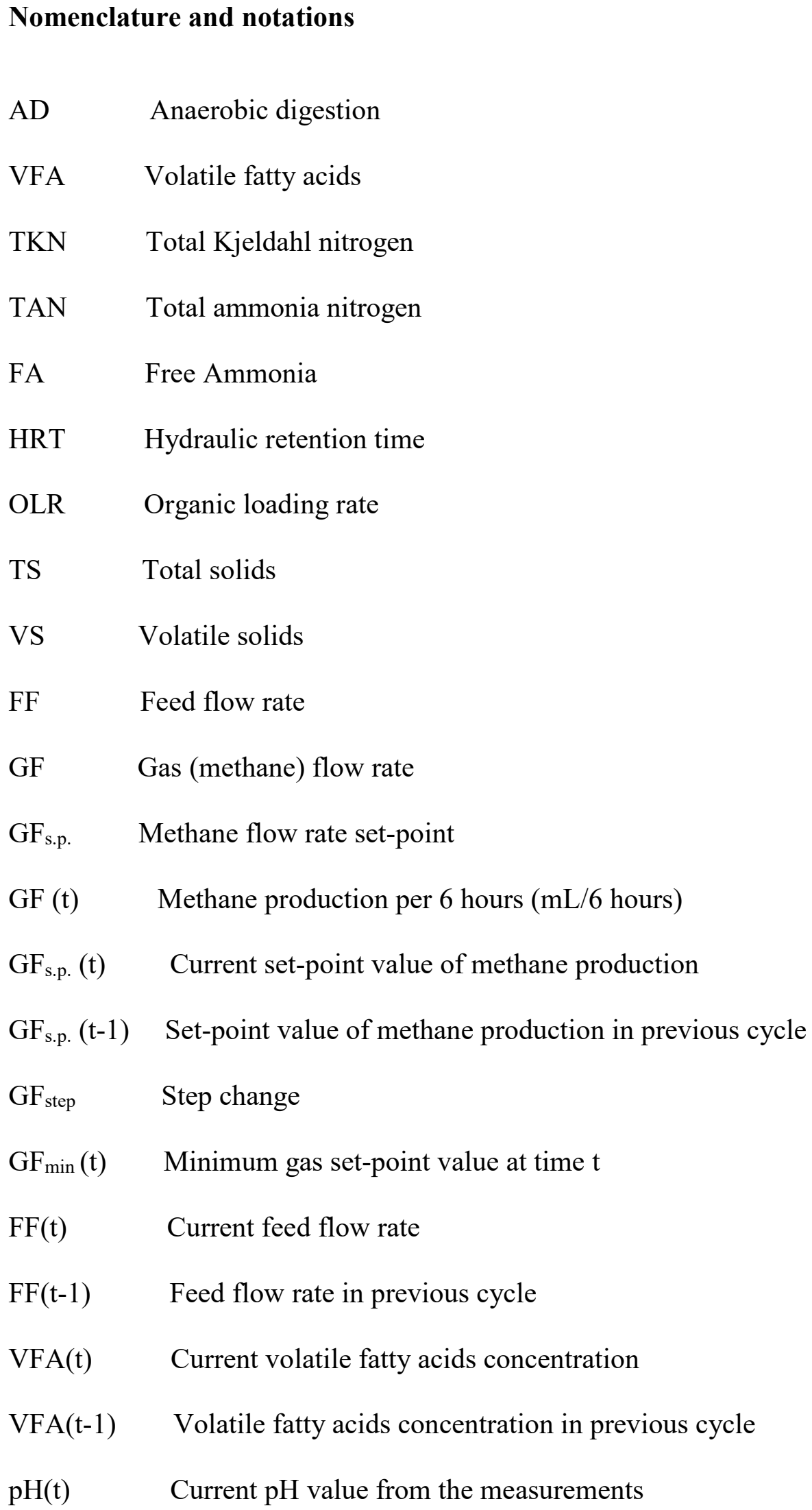




\begin{tabular}{|ll}
\hline DAQ & Data acquisition device \\
BMP & Biochemical methane potential
\end{tabular}

\section{Introduction}

Anaerobic digestion (AD) is a green technology that relies on metabolic activity of a diverse group of microorganisms for degradation of bio-wastes and production of biogas (a mixture of carbon dioxide (30-50\%) and methane (50-70\%)) as a green and renewable energy source. The main steps of the AD process are hydrolysis, acidogenesis, acetogenesis and methanogenesis. The stability of AD process relies on the balanced activity of the principal microbial guilds [1].

AD process offers several advantages because it decreases the environmental pollution caused by raw bio-waste, while providing clean energy and organic fertilizer[2,3]. Despite these advantages, low operational stability is still an important challenging problem in the commercial AD processes [4]. Process instability can lead to the process failure or compromise the economic efficiency [5].

Successful biogas production requires proper monitoring and control to improve the process efficiency and keep the process stable. The growing number of industrial biogas plants has led to the development of more advanced monitoring and control systems to keep the process stable. Furthermore, controlling the biological processes specially in complex systems, e.g. AD processes and wastewater treatment plants, is a very hard task since these processes are highly non-linear and their kinetics parameters are usually uncertain [6]. Biogas plants often suffer from overload or inhibition due to change of feedstock and they are usually run under sub-optimal condition to avoid process instability. Therefore utilizing proper controller is necessary to prevent biogas plants from failure. 
During the last years, various variables such as $\mathrm{pH}$, alkalinity, volatile fatty acids (VFAs) concentrations or biogas production rate have been used for online monitoring, and several control strategies have been proposed for controlling anaerobic digesters [68]. In industrial biogas plants, biogas production rate is commonly used as process indicator since it represents the overall process performance and can be easily measured by many robust online sensors [9]. Moreover, $\mathrm{pH}$ and titrimetric VFA estimation are applied in several biogas plants, although these values are not actively involved in process control. Taking biogas production as the only process state indicator is in many cases inadequate as the biogas production rate starts to decrease when the process is already damaged [10]. Thus, monitoring of biogas production rate is not enough for early detection of process imbalance to prevent failure in the bioreactor [11] and other indicators are needed [10].

Biogas production rate and $\mathrm{pH}$ are often the online measurements monitored in industrial biogas plants. However for systems with higher buffer capacity, such as those treating manures, $\mathrm{pH}$ becomes less sensitive to process imbalances. VFAs are formed as intermediates in acidogenesis and acetogenesis steps of the AD process and therefore VFA concentration is a more reliable indicator $[10,12,13]$.

Therefore, VFA concentration can be used as a suitable controlled variable [14-16]. In several investigations, control strategies that use either total or individual VFA concentrations as indicator to control anaerobic digesters have been tested experimentally. Puñal et al. [17] implemented a fuzzy logic based control strategy to control the VFA concentration in an anaerobic wastewater treatment process by manipulating the influent flow rate. Garcia-Sandoval et al. [18] designed a model-based 
output feedback controller to regulate the VFA concentration in an AD pilot plant by manipulating the inflow rate. Boe et al. [19] implemented a simple logic control with different tuning sets to control propionic acid concentration as individual VFA by manipulating the feed flow rate in a digester treating manure.

Boe and Angelidaki [20] developed a supervisory control strategy. The supervisory control scheme consisted of a rule based controller which used the biogas flow rate as the main controlled variable and the VFA concentrations (total VFA and propionate concentrations) as the secondary measurement. Low biogas production can be either as a result of process inhibition (imbalance state) or low reactor loading (underload condition). Their proposed control strategy was inadequate and could not control the process in the presence of long term underload because the gas set-point was decreased undesirably, despite the process was not inhibited. Therefore the proposed control strategy could not distinguish between substrate underload and the process inhibition [20].

This work aims to extend and improve the control strategy previously developed by Boe and Angelidaki [20] to increase the biogas production rate in an AD process subject to severe changes in the feedstock. In previous work, the VFA concentrations were not directly involved in control of the biogas production, but used for preventing the reactor from overloading (only as alarm states) [20] and the feed flow was set to zero for the next feeding in case of potential inhibition by VFA accumulation. However, no rule was available to track cases of reactor underload (e.g., reduction of the concentration of organics in the feedstock). Thus, the rule based control strategy was modified by using total VFA levels to distinguish between underload and inhibition conditions. On the other hand in the previous work, a fixed biogas yield parameter was used in the rule 
based controller which was not suitable for the full-scale biogas plants where the feedstock organic content can vary [20]. In the new control structure, a feedback proportional controller was used in the inner loop which received its set-point from the supervisory controller.

The proposed control strategy was examined not only under underload condition as done in the previous work, but also under other feedstock changes such as organic overload, ammonia inhibition and changing the feedstock (i.e. changing from manure to bio-pulp)

\section{Materials and methods}

\subsection{Substrates and inoculum}

Cattle manure was supplied from Hashøj full-scale biogas plant (Zealand, Denmark). Total solids (TS) and volatile solids (VS) of concentrated cattle manure were $110.62 \pm 0.35 \mathrm{~g} \mathrm{~kg}^{-1}$ and $86.95 \pm 0.12 \mathrm{~g} \mathrm{~kg}^{-1}$, respectively. Cattle manure was sieved and diluted with tap water ( $2 \%$ VS) to prevent clogging and provide efficient mixing and pumping. After sieving and dilution, the substrate was stored at $-20{ }^{\circ} \mathrm{C}$ before usage. Liquefied organic fraction of municipal solid waste (referred to bio-pulp) was also used as second substrate. Bio-pulp was collected from Gemidan Ecogi A/S after pulping process used to increase biodegradability [21]. TS and VS of concentrated bio-pulp were $166.27 \pm 0.44 \mathrm{~g} \mathrm{~kg}^{-1}$ and $143.43 \pm 0.25 \mathrm{~g} \mathrm{~kg}^{-1}$, respectively. Bio-pulp was diluted and mixed with tap water (6\% VS) and stored at $-20{ }^{\circ} \mathrm{C}$ before usage. Thermophilic inoculum was supplied from digestate of a well performing lab-scale reactor fed with cattle manure [22]. Prior to use, the digestate was degassed by incubating at thermophilic conditions for 10 days to reduce the background biogas production. In 
order to evaluate the controller performance, several step changes were introduced as summarized in Table 1. These changes included adding glucose or ammonia in the feedstock and shifting feedstock type. After any change, methane production, total VFA concentration, biogas composition and $\mathrm{pH}$ were measured to monitor the system dynamics. When the system reached pseudo-steady state (i.e., the disturbance was rejected and both methane productivity and total VFA levels were relatively constant), the next change was introduced.

First the reactor was fed with manure containing 2\% VS for 39 days to reach steady state. For organic overload, $40 \mathrm{~g} \mathrm{~L}^{-1}$ glucose were added to the manure on day 39 , thus inducing a step change (the VS changed from $2 \%$ to $6 \%$ ). To test ammonia inhibition $[23,24]$, ammonium chloride $\left(20 \mathrm{~g} \mathrm{~L}^{-1}\right.$, purity $\left.\geq 99.5 \%\right)$ was added to the mix of manure and glucose on day 68 , thereby increasing the ammonia concentration in the digester up to $6 \mathrm{~g} \mathrm{~L}^{-1}$. All chemicals purchased from Sigma-Aldrich and used without further purification and treatment. For evaluating reaction of the process upon reestablishing original conditions, on day 94, both glucose and ammonia were removed from the feedstock and the VS were returned to original level (2\%). The final disturbance was to completely shift to a new feedstock. On days 110 and 145, the feedstock was changed to bio-pulp and organic load increased to $6 \%$ VS.

The characteristics of inoculum and diluted substrates used in the experiments are presented in Table 2.

Table 1. Different feedstock changes used as disturbances to the process

\begin{tabular}{|c|c|c|}
\hline Steps introduced as disturbances & $\begin{array}{c}\text { Method of } \\
\text { addition }\end{array}$ \\
\hline
\end{tabular}




\begin{tabular}{|c|c|c|c|c|}
\hline & Glucose & $\begin{array}{c}\text { Ammonium } \\
\text { chloride }\end{array}$ & Bio-pulp & \\
\hline $39-68$ & $\checkmark$ & - & - & $\begin{array}{c}\text { Mixed with feed } \\
\text { (manure) }\end{array}$ \\
\hline $68-94$ & $\checkmark$ & $\checkmark$ & - & $\begin{array}{c}\text { Mixed with feed } \\
\text { (manure) }\end{array}$ \\
\hline $94-110$ & - & - & - & - \\
\hline $110-121$ & - & - & $\checkmark$ & $\begin{array}{c}\text { Feedstock change } \\
\text { (Bio-pulp) }\end{array}$ \\
\hline $121-145$ & - & - & - & $\begin{array}{c}\text { Feedstock change } \\
\text { (Manure) }\end{array}$ \\
\hline $145-170$ & - & - & $\checkmark$ & $\begin{array}{c}\text { Feedstock change } \\
\text { (Bio-pulp) }\end{array}$ \\
\hline
\end{tabular}

Table 2. Characteristics of the inoculum and feedstocks after dilution and before adding glucose or ammonia

\begin{tabular}{|c|c|c|c|}
\hline Characteristics & Cattle manure & Inoculum & Bio pulp \\
\hline $\mathrm{pH}$ & 7.52 & 8.15 & 4.23 \\
\hline $\mathrm{TS}, \mathrm{g} \mathrm{kg}^{-1}$ & $27.04 \pm 0.12$ & $29.54 \pm 0.22$ & $69.92 \pm 0.27$ \\
\hline $\mathrm{VS}, \mathrm{g} \mathrm{kg}^{-1}$ & $19.85 \pm 0.42$ & $19.78 \pm 0.25$ & $60.05 \pm 0.14$ \\
\hline TKN, $\mathrm{g} \mathrm{L}^{-1}$ & $1.98 \pm 0.24$ & $3.43 \pm 0.05$ & $1.44 \pm 0.03$ \\
\hline $\mathrm{TAN}, \mathrm{g}-\mathrm{NH}_{4}{ }^{+} \mathrm{L}^{-1}$ & $1.23 \pm 0.09$ & $3.18 \pm 0.12$ & $0.35 \pm 0.08$ \\
\hline Total VFA, $\mathrm{g} \mathrm{L}^{-1}$ & $3.24 \pm 0.1$ & $0.23 \pm 0.05$ & $1.23 \pm 0.04$ \\
\hline Acetate, $\mathrm{g} \mathrm{L}^{-1}$ & $2.71 \pm 0.08$ & $0.15 \pm 0.05$ & $0.95 \pm 0.01$ \\
\hline Propionate, $\mathrm{g} \mathrm{L}^{-1}$ & $0.17 \pm 0.00$ & $0.04 \pm 0.01$ & $0.13 \pm 0.00$ \\
\hline Isobutyrate, $\mathrm{g} \mathrm{L}^{-1}$ & $0.02 \pm 0.00$ & $0.03 \pm 0.01$ & $0.04 \pm 0.00$ \\
\hline Butyrate, $\mathrm{g} \mathrm{L}^{-1}$ & $0.25 \pm 0.01$ & $0.01 \pm 0.01$ & $0.00 \pm 0.00$ \\
\hline Iso-valerate, $\mathrm{g} \mathrm{L}^{-1}$ & $0.04 \pm 0.01$ & $0.00 \pm 0.00$ & $0.06 \pm 0.00$ \\
\hline Valerate, $\mathrm{g} \mathrm{L}^{-1}$ & $0.04 \pm 0.00$ & $0.00 \pm 0.00$ & $0.06 \pm 0.03$ \\
\hline N-hexanoate, $\mathrm{g} \mathrm{L}^{-1}$ & $0.00 \pm 0.00$ & $0.00 \pm 0.00$ & $0.00 \pm 0.00$ \\
\hline
\end{tabular}




\subsection{Experimental setup}

The experimental set up consisted of a continuously stirred tank reactor (CSTR) with 9.0 L total and 7.5 L working volumes (Fig. 1) operated at thermophilic conditions $\left(54 \pm 1{ }^{\circ} \mathrm{C}\right.$ ). The minimum HRT of digester was considered 5 days. A 2-L gas trap (with 1.8 $\mathrm{L}$ working volume), containing $2.5 \% \mathrm{NaOH}$ aqueous solution, was used to eliminate $\mathrm{CO}_{2}$ and $\mathrm{H}_{2} \mathrm{~S}$ from produced gas [25]. The alkaline solution was refreshed before saturation based on gas analysis. An automated displacement gas metering system with a $100 \mathrm{~mL}$ reversible cycle and registration was used to measure methane production rate [26]. A peristaltic pump was used to feed the reactor every 6 hours. Mixing intensity and continuous mixing can break the structure of microbial flocks [27,28]. Therefore the reactor was mixed in an on/off mode (30 seconds on, one minute off) at $80 \mathrm{rpm}$.

The setup was equipped with a data acquisition (DAQ) device (NI USB-6008 BusPowered Multifunction I/O Device, National Instruments, Austin, TX, USA) together with a PC to collect and record the methane production rate every 6 hours. Moreover, a control algorithm was programmed in LabVIEW2016 software (National Instruments, Austin, TX, USA) to change the manipulated variable (i.e. feed flow rate) based on the control strategy described in section 2.4 .

Methane production was measured online, while total VFAs concentration and $\mathrm{pH}$ were measured offline 2 times per day. The daily average value of total VFAs measurements was used as monitored variable by the supervisory controller. Biogas composition (before the gas trap) was measured offline 3 times per week, while it was measured once or twice per day after introducing disturbances. Concentration of each individual VFA (acetic acid, propionic acid, butyric acid, iso-butyric acid and valeric acid) was 
measured before and after each feedstock changes and during steady state condition.

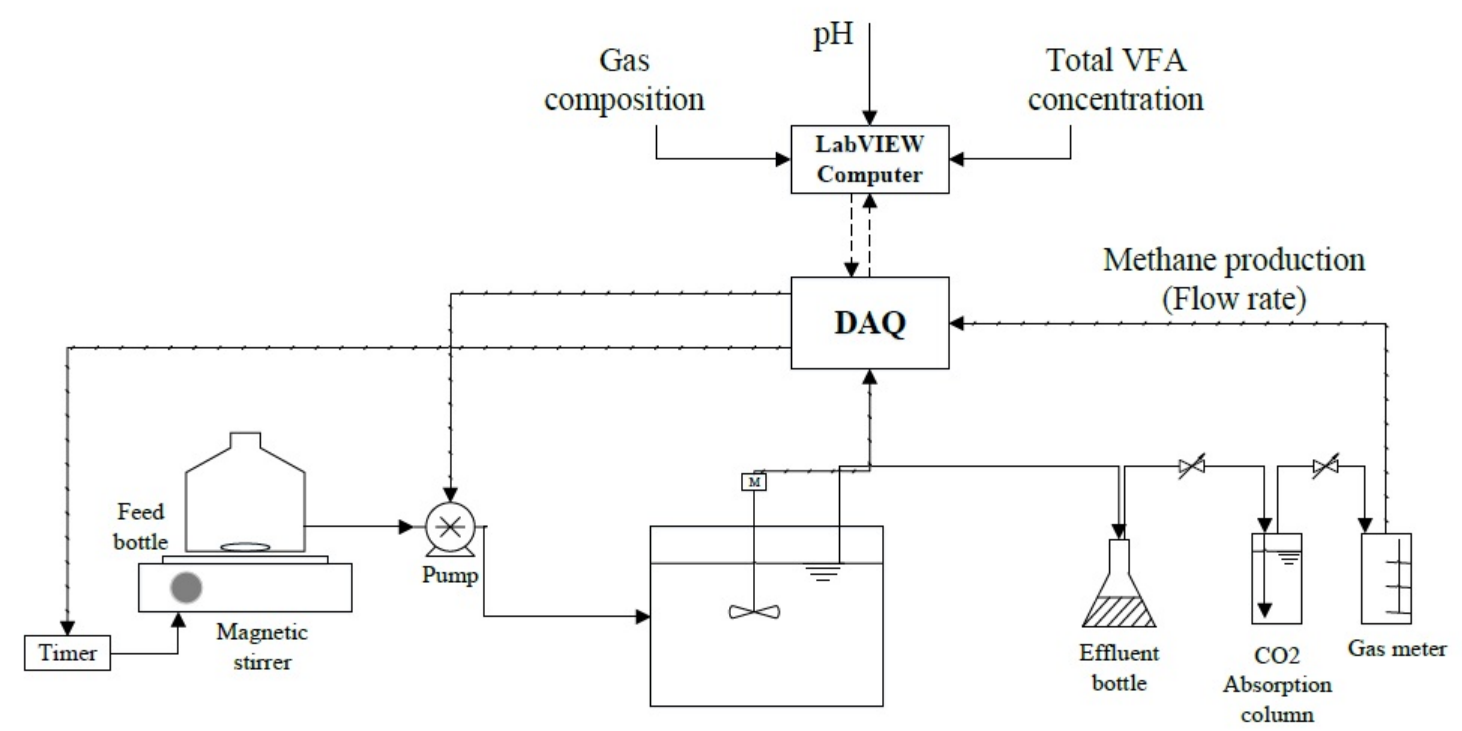

Figure 1. Schematic of experimental setup [DAQ; data acquisition device, VFA; volatile fatty acids].

\subsection{Bio-methane potential tests}

To determine the anaerobic biodegradability and biogas production of the reactor effluent, biochemical methane potential tests (BMPs) were performed in triplicate under thermophilic conditions $\left(54 \pm 1{ }^{\circ} \mathrm{C}\right)$ during 25 days. Glass serum bottles with total and working volumes of $250 \mathrm{~mL}$ and $75 \mathrm{~mL}$ were used as batch reactors for BMP experiments. During CSTR achieved steady state, several effluent samples were taken at time intervals, i.e. twice per week, and stored at $-20^{\circ} \mathrm{C}$ to be used as substrate of BMP experiments. Triplicate of batch reactors containing $17 \mathrm{~mL}$ of substrate, i.e. reactor effluent, and $58 \mathrm{~mL}$ of inoculum were prepared in order to determine the specific biomethane production of digestate. Two more batch assays in triplicate were conducted as control tests ( $58 \mathrm{~mL}$ of inoculum $+17 \mathrm{~mL}$ of reactor feedstock) to obtain the maximum 
methane yield of cattle manure and bio-pulp as basic substrates during the reactor operation. To properly estimate the bio-methane potential of the different substrates, blank assays were performed containing only $75 \mathrm{~mL}$ inoculum and its production was subtracted from the total biogas production. In addition, the same bottles containing 75 $\mathrm{mL}$ inoculum and $0.15 \mathrm{~g}$ of model substrate (Avicel) were prepared and incubated as control experiments to validate the accuracy of experiments. In order to ensure anaerobic condition, all serum bottles were flushed with $\mathrm{N}_{2}$ gas flow for 5 minutes and immediately sealed with butyl rubber stoppers and aluminium crimps. Subsequently the bottles were incubated at $54{ }^{\circ} \mathrm{C}$, until no significant gas production was observed in two consecutive measurements (25 days). In order to provide homogenous condition and avoiding dead zones, bottles were shaken manually once a day until the end of process. Biogas was taken from headspace of the glass bottles and methane concentration was measured three times at the first week and then twice per week until the end of process.

\subsection{Control strategy}

The control purpose was to improve methane production rate, while keeping the reactor stable in the presence of disturbances (i.e., glucose overload, ammonia inhibition, underload condition and shift to bio-pulp). Minimum hydraulic retention time (HRT) was set to 5 days to prevent wash out of methanogens from the bioreactor. Feed flow rate (controlled by manipulating the influent pumping time) was chosen as the manipulated variable.

The supervisory control structure is shown in Fig. 2, where total VFAs concentration, $\mathrm{pH}$ and methane production rate were the measured variables. The inner loop was a feedback control loop using a proportional controller $(\mathrm{P})$ that manipulated the feed flow rate (FF). The rule based outer loop controller (Table 3) used the gas flow rate (GF) 
trend and the total VFA concentration in the reactor to provide the set-point of the inner loop. Methanogenesis takes place in a $\mathrm{pH}$ range about 6.5 to 8.5 [29].Thus, to prevent the system from acidification, an inter-lock system was considered based on the $\mathrm{pH}$ measurement in the reactor. If $\mathrm{pH}$ fell below 6 , the feed flow rate was set to zero for the next cycle. Otherwise the supervisory controller remained active.

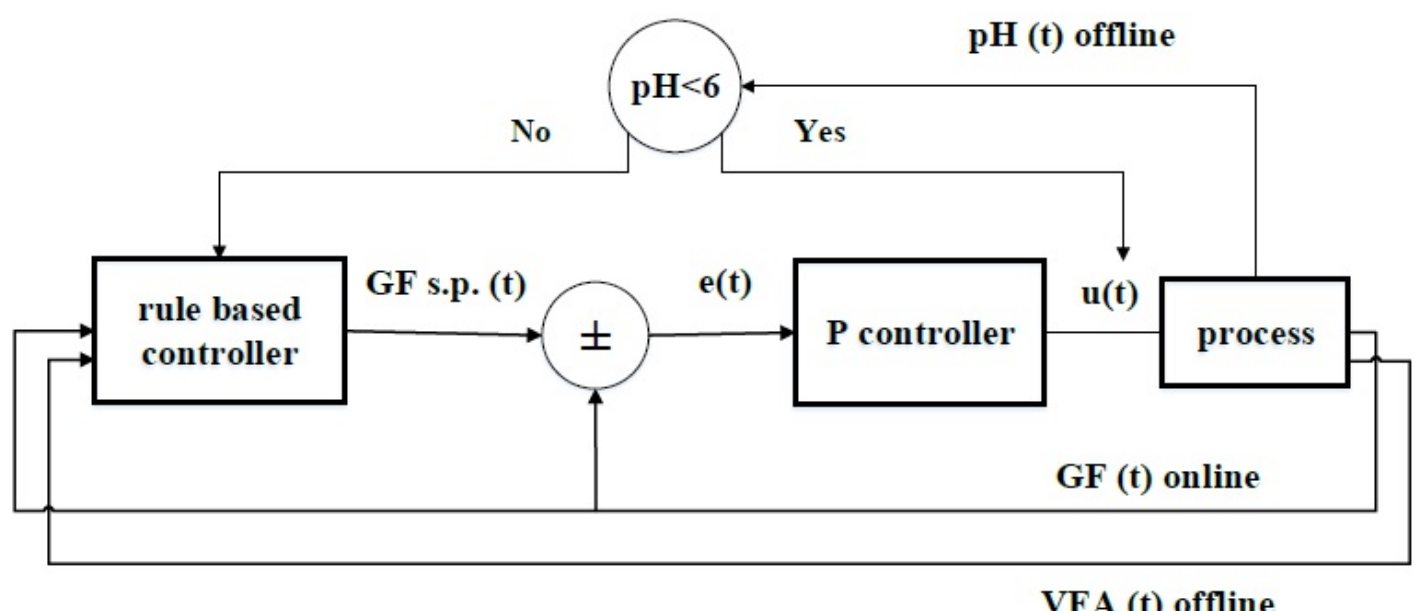

Figure 2. Supervisory control block diagram $[\mathrm{u}(\mathrm{t})$ : pump working time (manipulated variable); GF: Gas flow rate; $\mathrm{GF}_{\text {s.p. }}$ Gas flow rate set-point; $\mathrm{e}(\mathrm{t})$ : error $=\mathrm{GF}_{\text {s.p. }}-\mathrm{GF}$; VFA: volatile fatty acids; P controller: proportional controller].

It should be noted that the control system had no knowledge regarding the type of external disturbances and acted based on output measurements. This is crucial for environmental biotechnologies, where there are limited availability of sensors and therefore, limited possibilities to apply control strategies [30] and disturbances may have many different origins difficult to characterize online. The total VFA concentration and methane production rate measurements were used at the supervisory level to select the appropriate rule as given in Table 3, thus updating the set-point of the inner loop. 
The proportional gain of controller $\left(\mathrm{K}_{\mathrm{c}}=0.1\right)$ was calculated based on the data derived from a step change in feed flow rate reported in previous research [10] using the Internal Model Control (IMC) technique [31]. The rules (12 rules) for supervisory control are presented in Table 3. The corresponding flowchart for selecting the appropriate rule is given in Fig. 3 .

The error of the inner loop was defined as difference between GF and $\mathrm{GF}_{\text {s.p. }}$ in each cycle. The parameter $\mathrm{GF}_{\text {step }}$ value was set to $225 \mathrm{~mL} \mathrm{day}^{-1}$ and was calculated as follows. The average methane potential in a preliminary batch experiment was $150 \mathrm{~mL}$ $\mathrm{CH}_{4} \mathrm{~g}^{-1}$ VS. For the operation of the CSTR, the initial OLR was set to $2 \mathrm{~g} \mathrm{VS} \mathrm{L}_{\text {reactor }}{ }^{-1}$ day $^{-1}$. The $\mathrm{GF}_{\text {step }}$ value was set to $10 \%$ of the average methane production rate of the batch experiment. The $\mathrm{GF}_{\min }$ was calculated as $90 \%$ of $\mathrm{GF}_{\text {s.p. }}$.

To avoid acidification, the $\mathrm{pH}$ in the reactor was monitored regularly. If $\mathrm{pH}<6$, the feed flow rate was set to zero and $\mathrm{GF}_{\text {s.p. }}(\mathrm{t})$ was kept constant.

The rule based controller consisted of different actions which were selected based on the following conditions:

1) If $\mathrm{GF}(\mathrm{t}) \geq \mathrm{GF}_{\text {s.p. }}(\mathrm{t}-1), \mathrm{GF}_{\text {s.p. }}(\mathrm{t})$ is increased one step $\left(\mathrm{GF}_{\text {step }}\right)$ and the error at time $t$ is calculated. If the error is positive, the calculated set-point is used for control purpose in the coming cycle. This rule indicates that microorganisms can manage the OLR increase [20]. Moreover in case of negative error, the feed flow rate $(\mathrm{FF}(\mathrm{t}))$ is set to its value in the previous cycle. See control action section in Table 3.

2) If $\mathrm{GF}_{\min }(\mathrm{t}-1) \leq \mathrm{GF}(\mathrm{t})<\mathrm{GF}_{\text {s.p. }}(\mathrm{t}-1), \mathrm{GF}_{\text {s.p. }}(\mathrm{t})$ is increased half a step $\left(0.5 \times \mathrm{GF}_{\text {step }}\right)$. At this state, microorganisms are working very close to their maximum capacity and they may be limited to manage a large increase on OLR 
[20]. In this case the error is always positive and FF will be increased by the $\mathrm{P}$ controller.

3) If $\mathrm{GF}(\mathrm{t})<\mathrm{GF}_{\min }(\mathrm{t}-1)$ and the system has been in state 1 in previous cycle, $\mathrm{GF}_{\text {s.p. }}$ (t) should be kept constant. It means despite increase in set-point in previous cycle (state 1), the current methane production rate could not reach to the setpoint [20] and decreased to the value lower than $\mathrm{GF}_{\min }(\mathrm{t}-1)$. In this case the $\mathrm{FF}(\mathrm{t})$ should not be increased and is set to $\mathrm{FF}(\mathrm{t}-1)$.

4-9) The system is under inhibition if GF $(\mathrm{t})<\mathrm{GF}_{\min }(\mathrm{t}-1)$, the system has not been in state 1 in previous cycle and the total VFA concentration is higher than $2 \mathrm{~g} \mathrm{~L}^{-1}$. In this case, $\mathrm{GF}_{\text {s.p. }}$ (t) should be decreased. During system inhibition if $F F(t)>F F(t-1), F F(t)$ should be set to $F F(t-1)$ to avoid further VFA accumulation and $\mathrm{pH}$ reduction in the reactor. Otherwise feed flow rate is set to $F F(t)$. Rules 4 to 9 were considered as different levels of inhibition. In order to have an efficient performance in presence of a wide range of disturbances, three different situations based on total VFA concentration were defined: 2-4 $\mathrm{g} \mathrm{L}^{-1}, 4-6 \mathrm{~g} \mathrm{~L}^{-1}$ and higher than $6 \mathrm{~g} \mathrm{~L}^{-1}$. In each VFA range, pending on the total VFA concentration change, the set-point change is different, as shown in Table 3. As can be observed from these rules, the set-point decreases half a step $\left(0.5^{*} \mathrm{GF}_{\text {step }}\right)$, one step or two steps depending on total VFA concentration level.

10) If GF (t) $<G F_{\min }(\mathrm{t}-1)$ and the system has been in one of the inhibition states (rules 4-9) in previous cycle and the total VFA concentration is less than $2 \mathrm{~g} \mathrm{~L}^{-1}$, $\mathrm{GF}_{\text {s.p. }}(\mathrm{t})$ should be kept constant. Moreover, if FF (t) $>$ FF ( $\left.\mathrm{t}-1\right)$, FF (t-1) should be considered as current feed flow rate $(\mathrm{FF}(\mathrm{t}))$. Otherwise feed flow rate is set to 
$\mathrm{FF}(\mathrm{t})$. In this situation, the system has been inhibited in the previous cycle and any increase in the current FF may force the system to return to the inhibition state.

11) If $G F(t)<G F_{\min }(t-1)$ and the system has not been in state 1 and none of the inhibition states (rules 4-9) in the previous cycle, the total VFA concentration should be checked. If total VFA concentration is less than $2 \mathrm{~g} \mathrm{~L}^{-1}$ and is increasing, $\mathrm{GF}_{\text {s.p. }}(\mathrm{t})$ should be kept constant. This means that the system is still stable, but probably close to the inhibition because total VFA concentration is increasing. Therefore if FF ( $\mathrm{t})>\mathrm{FF}(\mathrm{t}-1)$, FF ( $\mathrm{t}-1)$ should be considered as current feed flow rate $(\mathrm{FF}(\mathrm{t}))$ to avoid further VFA accumulation. Otherwise feed flow rate is set to $\mathrm{FF}(\mathrm{t})$.

12) If $\mathrm{GF}(\mathrm{t})<\mathrm{GF}_{\min }(\mathrm{t}-1)$ and the system has not been in states 1 and none of inhibition states (rules 4-9) in the previous cycle and the total VFA concentration is less than $2 \mathrm{~g} \mathrm{~L}^{-1}$ and is decreasing respect to the previous total VFA concentration (VFA (t-1)), GF s.p. $(\mathrm{t})$ should be increased by half a step $\left(0.5^{*} \mathrm{GF}_{\text {step }}\right)$. Moreover, if FF $(\mathrm{t})<\mathrm{FF}(\mathrm{t}-1), \mathrm{FF}(\mathrm{t}-1)$ should be considered as current feed flow rate $(F F(t))$. Otherwise feed flow rate is set to $F F(t)$. This state indicates underload condition. The system is stable and it is capable to handle more FF and produce more biogas.

Total VFA concentration thresholds for inhibition were chosen based on typical values found in digesters treating manure $\left(1-2 \mathrm{~g} \mathrm{~L}^{-1}\right)[32]$.

\section{Table 3. Rule based controller}




\begin{tabular}{|c|c|c|c|}
\hline Rule No. & Conditions & Set-point adjustment & Control action \\
\hline 1 & if $G F(t) \geq G F_{\text {set point }}(t-1)$ & $\begin{array}{l}G F_{\text {set point }}(t) \\
=G F_{\text {set point }}(t-1) \\
+G F_{\text {step }}\end{array}$ & $\begin{array}{l}\text { if } e(t)>0 \\
F F(t)^{*}=F F(t) \\
\text { otherwise } \\
F F(t)=F F(t-1)\end{array}$ \\
\hline 2 & if $\quad G F_{\min }(t-1) \leq G F(t)<G F_{\text {set point }}(t-1)$ & $\begin{array}{l}G F_{\text {set point }}(t) \\
=G F_{\text {set point }}(t-1) \\
+0.5 \times G F_{\text {step }}\end{array}$ & $F F(t)=F F(t)$ \\
\hline 3 & if $G F(t)<G F_{\min }(t-1)$ and $\quad$ previouslyat state 1 & $\begin{array}{l}G F_{\text {set point }}(t) \\
=G F_{\text {set point }}(t-1)\end{array}$ & $\begin{array}{l}F F(t) \\
=\min [F F(t-1), F F(t)]\end{array}$ \\
\hline 4 & $\begin{array}{l}\text { if } G F(t)<G F_{\min }(t-1) \text { and previously not at state } 1 \\
\text { and } 2 \leq V F A(t)<4 g / L \text { and } \\
V F A(t)-V F A(t-1) \leq V F A(t-1)\end{array}$ & $\begin{array}{l}G F_{\text {set point }}(t) \\
=G F_{\text {set point }}(t-1) \\
-0.5 G F_{\text {step }}\end{array}$ & $\begin{array}{l}F F(t) \\
=\min [F F(t-1), F F(t)]\end{array}$ \\
\hline 5 & $\begin{array}{l}\text { if } G F(t)<G F_{\min }(t-1) \text { and previously not at state } 1 \\
\text { and } 2 \leq V F A(t)<4 g / L \text { and } \\
V F A(t-1)<V F A(t)-V F A(t-1)<2 * V F A(t-1)\end{array}$ & $\begin{array}{l}G F_{\text {set point }}(t) \\
=G F_{\text {set point }}(t-1) \\
-G F_{\text {step }}\end{array}$ & $\begin{array}{l}F F(t) \\
=\min [F F(t-1), F F(t)]\end{array}$ \\
\hline 6 & $\begin{array}{l}\text { if } G F(t)<G F_{\min }(t-1) \text { and previously not at state } 1 \\
\text { and } 2 \leq V F A(t)<4 g / L \text { and } \\
2 * V F A(t-1) \leq V F A(t)-V F A(t-1)\end{array}$ & $\begin{array}{l}G F_{\text {set point }}(t) \\
=G F_{\text {set point }}(t-1) \\
-2 * G F_{\text {step }}\end{array}$ & $\begin{array}{l}F F(t) \\
=\min [F F(t-1), F F(t)]\end{array}$ \\
\hline 7 & $\begin{array}{l}\text { if } G F(t)<G F_{\min }(t-1) \text { and previously not at state } 1 \\
\text { and } 4 \leq V F A(t)<6 g / L \text { and } \\
V F A(t)-V F A(t-1)<V F A(t-1)\end{array}$ & $\begin{array}{l}G F_{\text {set point }}(t) \\
=G F_{\text {set point }}(t-1) \\
-G F_{\text {step }}\end{array}$ & $\begin{array}{l}F F(t) \\
=\min [F F(t-1), F F(t)]\end{array}$ \\
\hline 8 & $\begin{array}{l}\text { if } G F(t)<G F_{\min }(t-1) \text { and previously not at state } 1 \\
\text { and } 4 \leq V F A(t)<6 \quad g / L \text { and } \\
V F A(t-1) \leq V F A(t)-V F A(t-1)\end{array}$ & $\begin{array}{l}G F_{\text {set point }}(t) \\
=G F_{\text {set point }}(t-1) \\
-2 * G F_{\text {step }}\end{array}$ & $\begin{array}{l}F F(t) \\
=\min [F F(t-1), F F(t)]\end{array}$ \\
\hline 9 & $\begin{array}{l}\text { if } G F(t)<G F_{\min }(t-1) \text { and previouslynot at state } 1 \\
\text { and } \quad 6 \leq V F A(t) g / L\end{array}$ & $\begin{array}{l}G F_{\text {set point }}(t) \\
=G F_{\text {set point }}(t-1) \\
-2 * G F_{\text {step }}\end{array}$ & $\begin{array}{l}F F(t) \\
=\min [F F(t-1), F F(t)]\end{array}$ \\
\hline 10 & $\begin{array}{l}\text { if } \quad G F(t)<G F_{\min }(t-1) \quad \text { and } \\
\text { previously at one of states of } 4 \text { to } 9 \\
\text { and } V F A(t)<2 \quad g / L\end{array}$ & $\begin{array}{l}G F_{\text {set point }}(t) \\
=G F_{\text {set point }}(t-1)\end{array}$ & $\begin{array}{l}F F(t) \\
=\min [F F(t-1), F F(t)]\end{array}$ \\
\hline 11 & $\begin{array}{l}\text { if } \quad G F(t)<G F_{\min }(t-1) \quad \text { and } \\
\text { none of states } 4 \text { to } 9 \\
\text { and } V F A(t)<2 \quad g / L \text { and } \quad V F A(t) \geq V F A(t-1)\end{array}$ & $\begin{array}{l}G F_{\text {set point }}(t) \\
=G F_{\text {set point }}(t-1)\end{array}$ & $\begin{array}{l}F F(t) \\
=\min [F F(t-1), F F(t)]\end{array}$ \\
\hline 12 & $\begin{array}{l}\text { if } \quad G F(t)<G F_{\min }(t-1) \text { and } \\
\text { previously not at state } 1 \text { and } \\
\text { none of states } 4 \text { to } 9 \\
\text { and } V F A(t)<2 \quad g / L \text { and } \quad V F A(t)<V F A(t-1)\end{array}$ & $\begin{array}{l}G F_{\text {set point }}(t) \\
=G F_{\text {set point }}(t-1) \\
+0.5 G F_{\text {step }}\end{array}$ & $\begin{array}{l}F F(t) \\
=\max [F F(t-1), F F(t)]\end{array}$ \\
\hline
\end{tabular}




\begin{tabular}{|l|l|l|}
\hline 13 & $\begin{array}{l}\text { if } \quad F F(t)=F F_{\text {max }} \\
F F_{\text {max }}: \text { is the maximum allowable feed flow rate to prevent wash out }\end{array}$ & $\begin{array}{l}G F_{\text {set point }}(t) \\
=G F_{\text {set point }}(t-1)\end{array}$ \\
\hline
\end{tabular}

${ }^{*} F F(t)$ is the output of Proportional controller

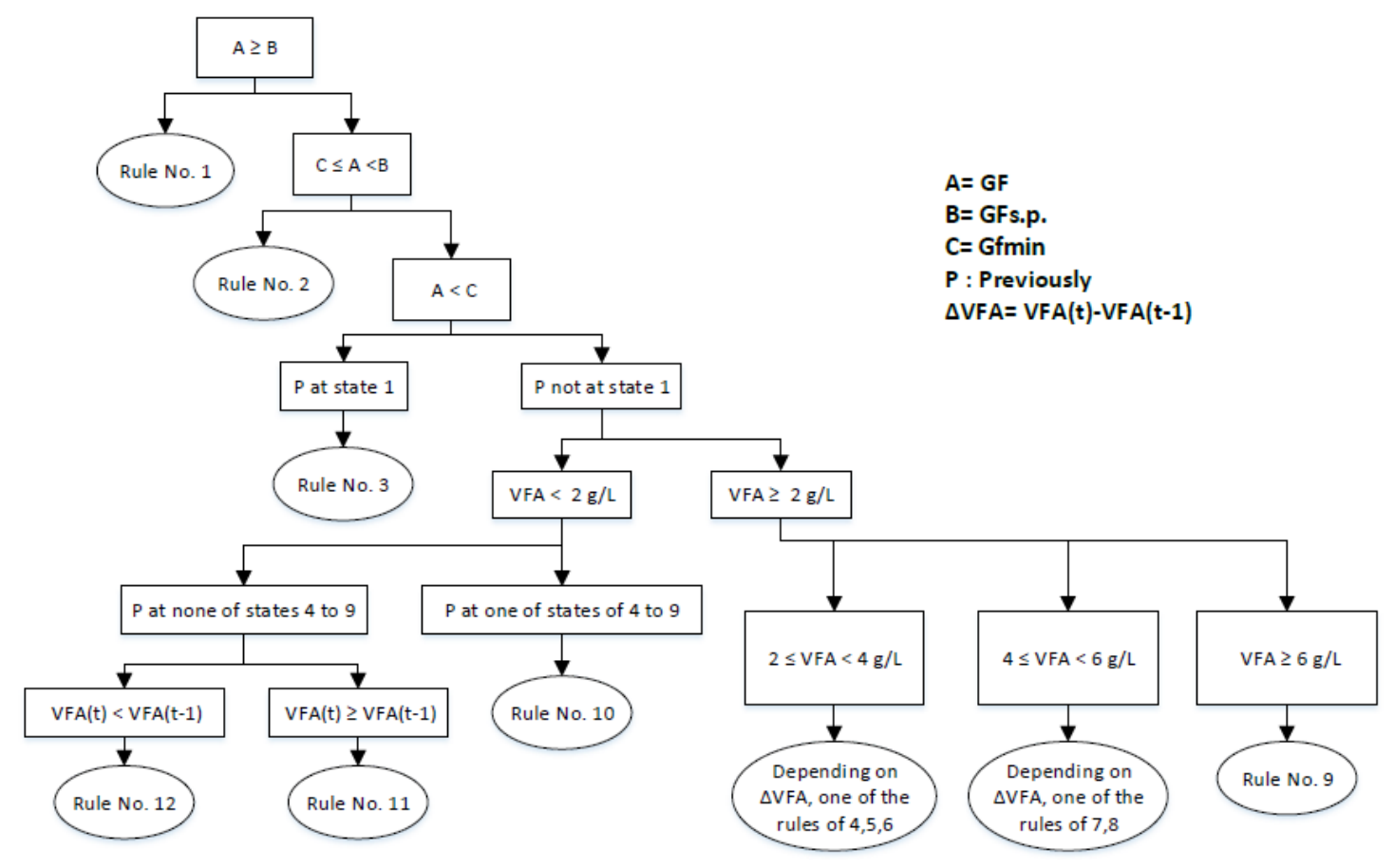

Figure 3. Flowchart for selecting the appropriate rule.

\subsection{Analytical methods}

The American Public Health Association (APHA) standard methods were followed to measure TS, VS, pH, TAN, and TKN [33]. Biogas composition was analysed by a gas chromatograph (GC-TRACE 1310, Thermo Fisher Scientific, US) equipped with a thermal conductivity detector (TCD) and Thermo (P/N 26004-6030) Column (30 m length, $0.320 \mathrm{~mm}$ inner diameter, and film thickness $10 \mu \mathrm{m}$ ) with helium as carrier gas. Total VFA concentration was measured based on two $\mathrm{pH}$ end-points titration method [34]. Individual VFA concentrations were also measured (Fig. S2 Supplementary 
material) using GC-TRACE 1300 (Thermo Fisher Scientific, US) equipped with a flame ionization detector (FID) and Agilent J \& W capillary Column (30 m length, $0.530 \mathrm{~mm}$ inner diameter, film thickness $1.50 \mu \mathrm{m}$ ) with helium as carrier gas. The accuracy of two $\mathrm{pH}$ end-points titration method was compared with that of GC technique and presented in Fig. S1 (supplementary material).

\section{Results and Discussion}

The system run for 170 days with the given rules in Table. 3 and the results are discussed in what follows.

\subsection{Start-up of the reactor}

The digester was fed with manure (2\% VS) for 39 days (Figs. 4 and 5). Methane setpoint and feed flow rate were set to zero as initial values, so the control strategy controlled the start-up operation. The initial HRT was set to 15 days as the typical HRT for stable operation of anaerobic digestion under thermophilic condition is in the range of 10 to 20 days [35,36]. As shown in Fig. 4a the methane production rate was

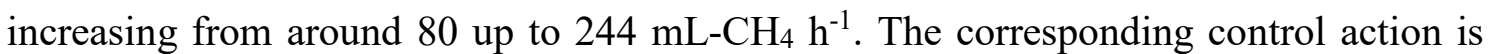
shown in Fig. 4d. The OLR (Fig. 5a) gradually increased during start-up period from 1.56 (at first day) to $3.13 \mathrm{~g} \mathrm{VS} \mathrm{L}^{-1}$ day $^{-1}$ (day 39) which was in accordance with recommended OLR range (2-3 $\mathrm{g} \mathrm{VS} \mathrm{L}^{-1}$ day $\left.^{-1}\right)$ for stable operation [35,36]. Total VFA concentration oscillated below $0.4 \mathrm{~g} \mathrm{~L}^{-1}$, which is below the inhibition levels for methanogenesis (Fig. 4b). The HRT decreased from 15 to 6.4 days by the end of startup period (Fig. 5d). pH values were within typical values for stable operation of AD process with average value of $7.79 \pm 0.07$ (Fig. 4c). Average methane percentage in the produced biogas during the start-up period was $69.70 \% \pm 1.64 \%$ (Fig. $5 \mathrm{c}$ ). which was in accordance with the percentage of methane in biogas reported for an efficient AD 
process (methane (50-70\%)) [1].

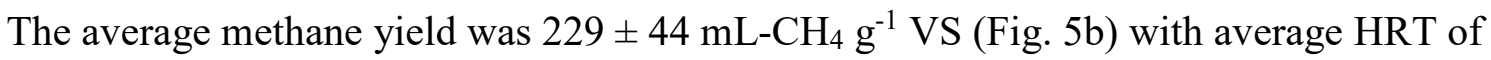
$7 \pm 0.51$ days during the continuous operation and VS reduction was $11.94 \%$. The low VS reduction suggests that hydrolysis may have been the rate limiting step during digestion of cattle manure due to hardly biodegradable lignocellulosic fibers. This result was confirmed by the methane production residual of the digestate (batch assays) given in Table. S3 (Supplementary material).

The cumulative methane yield from batch digestion (during 25 days) of $2 \% \mathrm{VS}$ raw

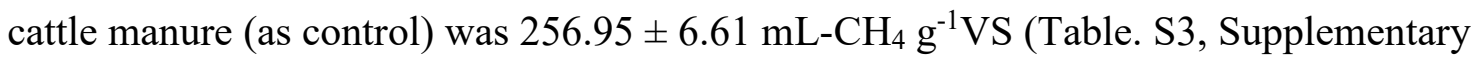
material), above the observed yield in the CSTR as HRT was higher. The achieved methane yields, both in batch and continuous assays, were higher than literature values

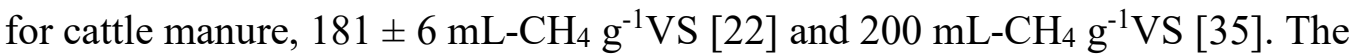
difference in the yields reported in literature depend largely on the content of lignocellulosic fibers because they are hardly degradable [37]. 

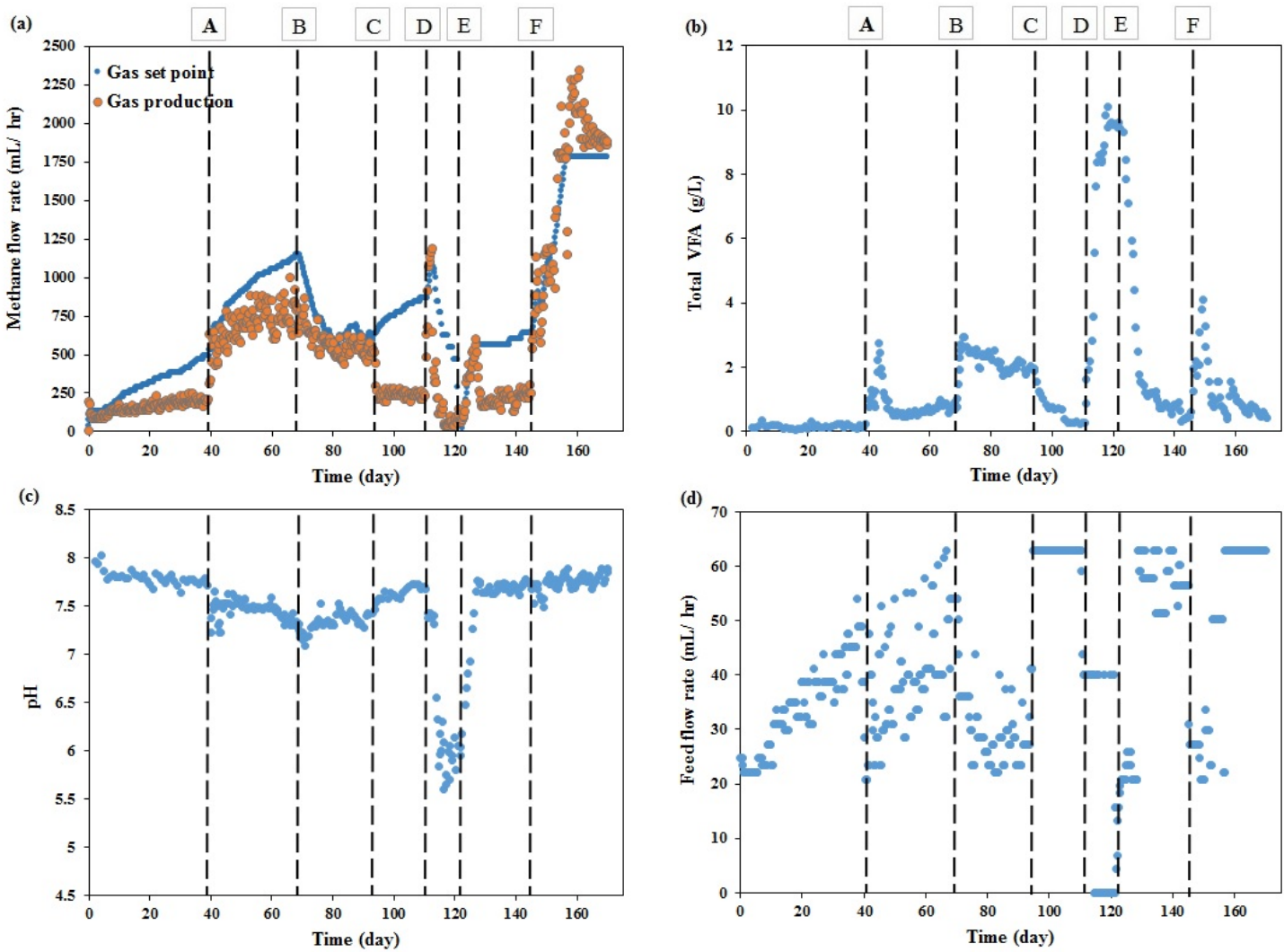

Figure 4. Reactor performance through 170 days; Vertical lines indicate time when the substrate was changed. Point A: organic overload by adding glucose (2\% to $6 \% \mathrm{VS})$ [from day 39 to day 68]; Point B: ammonia inhibition by adding ammonium chloride (ammonia concentration: $6 \mathrm{~g}$ $\mathrm{L}^{-1}$ ) [from day 68 to 94]; Point C: organic underload by stopping the addition of glucose and ammonium chloride, thus returning to $2 \%$ VS [from day 94 to 110 ]; Point D: changing the feed to bio-pulp containing 6\% VS [from day 110 to 121]; Point E: back to manure with 2\% VS [from day 121 to 145]; Point F: changing the feed to bio-pulp containing 6\% VS [from day 145 to 170]. a) Methane flow rate and set-point; b) Total volatile fatty acids (VFA) concentration based on titration method; c) Digester pH; d) Feed flow rate (manipulated variable). 

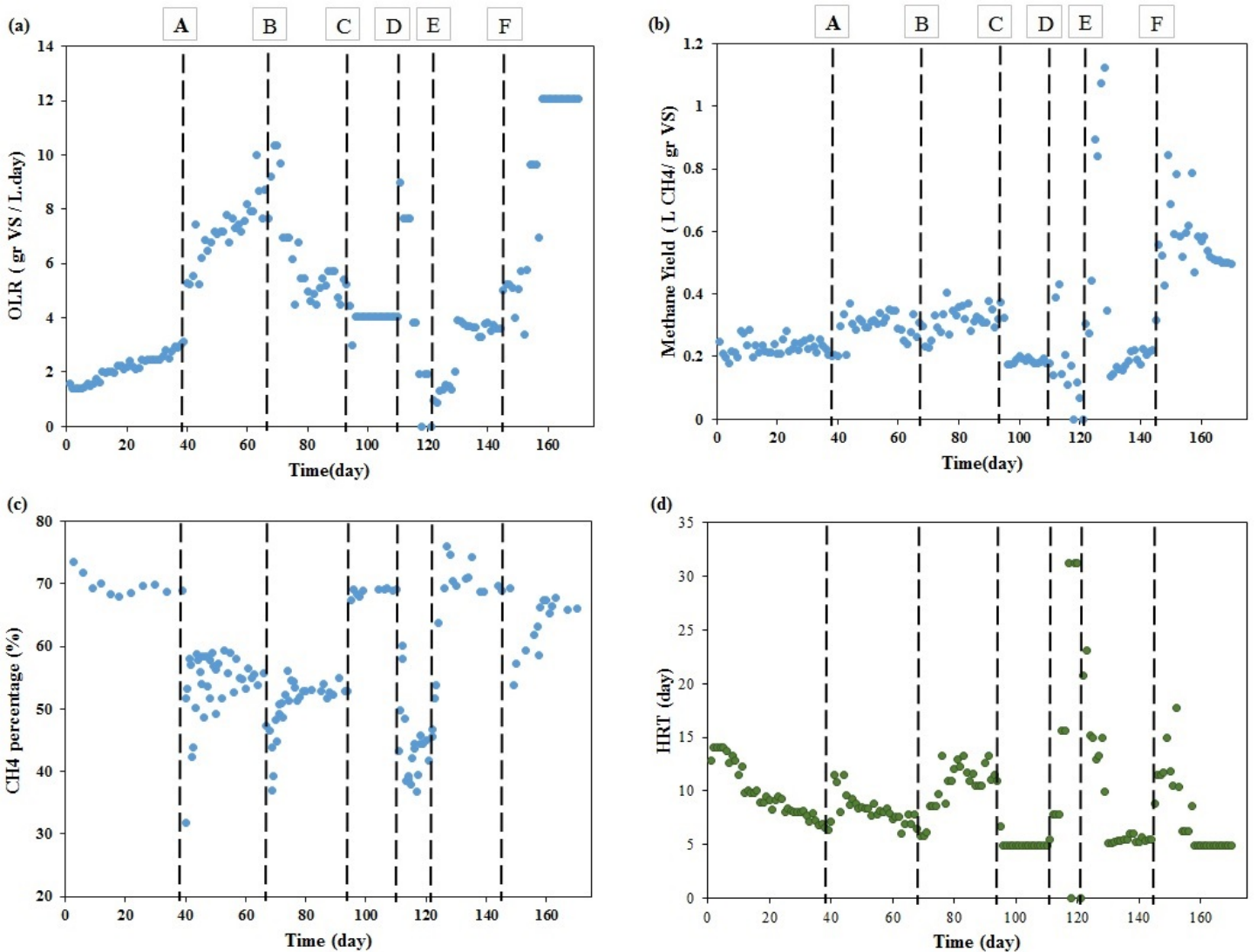

Figure 5. a) Organic loading rate; b) Methane yield; c) Methane percentage; d) Hydraulic retention time. Points A to $\mathrm{F}$ have the same definition given in Fig. 4.

\subsection{Glucose step}

On day 39 (point A in Figs. 4 and 5), the VS was increased from 2\% to $6 \%$ by adding glucose to the feed. Methane production instantly boosted (Fig. 4a). However, the total VFA (Fig. 4b) started to accumulate in the reactor as a consequence of the faster activity of acidogens compared to methanogens [38]. Despite accumulation of VFA, $\mathrm{pH}$ change (decrease on 0.57 units, Fig. 4c) was not large enough during this period (39-43 days) due to the manure buffer capacity [13]. Methane percentage (Fig. 5c) decreased down to $31.86 \%$ (day 40 ) as a result of VFA accumulation and methanogens inhibition [39]. It has been reported that low methane content (i.e. high carbon dioxide percentage) could 
indicate process imbalance and it is a traditional parameter indicator of process instability [40]. When total VFA concentration increased above the allowed value (e.g. on day 43), the supervisory controller started to decrease methane rate set-point and thus the feed flow rate by activating rules no. 4 to 9 (inhibition rules, Table 3) depending on the VFA levels. The controller prevented VFA accumulation above $2.73 \mathrm{~g} \mathrm{~L}^{-1}$ (day 43) and in few days (5 days after glucose addition) restored the VFA to the same level which was before glucose addition (Fig. 4b). After rejecting the disturbance (glucose addition), from day 44, the controller started to increase set-point and feed flow rate via rules no. 1-2 and 12 resulting in the increase of methane production rate (Fig.4a). It should be noted that, due to oscillation in methane production rate, rules no. 3 and 11 also became active during this period resulting in constant set-points for some periods and thus preventing inhibition due to VFA accumulation.

As the digester was stable and could manage more OLR, the OLR was gradually increasing up to $10 \mathrm{~g} \mathrm{VS} \mathrm{L}^{-1}$ day $^{-1}$ on day 63 (Fig. 5a). HRT was decreased to a minimum of 6.5 days by the end of this feedstock change (Fig. 5d), with an average

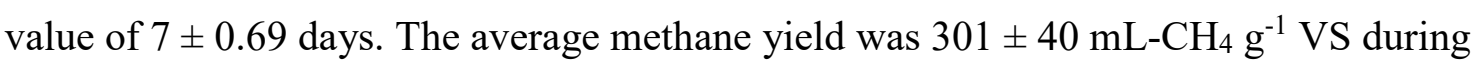
days 39 to 68 (Fig. 5b) and the VS reduction was 63.47\%, during this period. Despite reactor high organic load, the average methane yield was $31.4 \%$ higher than that of reactor start-up period.

Furthermore, the theoretical bio-methane potential of added glucose was calculated from Buswell's formula [41], assuming total conversion of organic material (glucose) to methane and carbon dioxide at STP condition. Comparing the theoretical and experimental BMPs of the added glucose, it was concluded that the methane production yield is $92 \%$ of the maximum theoretical value, indicating that most of glucose was 
converted into methane. This indicates that the hydrolysis was the rate limiting step, because for a feedstock such as manure (recalcitrant substrates) a higher HRT is required to reach this level of methane production yield.

The results indicate that the reactor was stable and controlled satisfactorily under high changes on organic load exerted by glucose addition. The supervisory controller protected the digester from VFA accumulation and subsequence process imbalance.

\subsection{Ammonia step}

On day 68 (point B in Figs. 4 and 5), ammonia content was increased up to $6 \mathrm{~g} \mathrm{~L}^{-1}$ by adding ammonium chloride, while keeping the same VS (6\%). Right after increasing the ammonia concentration, the methane production rate started to decrease due to methanogens inhibition resulting in VFA accumulation [42]. One day after ammonia addition, methane percentage (Fig. 5c) decreased down to $36.94 \%$ as a result of methanogens inhibition. On day 69 , the supervisory controller started to decrease methane production set-point and thus the feed flow rate via activation of rules no. 4 to 9 (inhibition rules, Table 3) for 6 days until total VFA concentration was below $2 \mathrm{~g} \mathrm{~L}^{-1}$. Thus controller prevented VFA accumulation above $2.94 \mathrm{~g} \mathrm{~L}^{-1}$ (day 71, Fig. 4b) by decreasing the feed flow rate (Fig. 4d), leading to decrease of OLR (Fig. 5a) and ammonia load.

Among four different types of microorganisms in the AD process, methanogens are the most sensitive group to ammonia inhibition and thus their growth ceases when exposed to high ammonia concentration $[43,44]$. Free ammonia has been reported as the main inhibition factor and toxic agent, since it freely passes through the microbial cell membrane $[45,46]$. A wide range of inhibition concentrations $\left(1.7-14 \mathrm{~g} \mathrm{~L}^{-1}\right)$ has been reported for ammonia causing up to $50 \%$ reduction in methane production $[42,45,47-$ 
49]. As a side effect, ammonia inhibition often causes VFA accumulation which leads to $\mathrm{pH}$ reduction in the digester, as observed in this study.

It can be seen from Fig. 4a that the average methane production rate was reduced $16 \%$ during this period (68 to 94 days) respect to previous period (39 to 68 days). Indeed, the interaction between free ammonia and VFAs can lead to an inhibited steady state condition as shown in Figs. $4 \mathrm{a}$ and $4 \mathrm{~b}$, where the process is running stable but with lower methane production $[50,51]$.

The methane yield during whole period of ammonia inhibition is shown in Fig. $5 b$ with

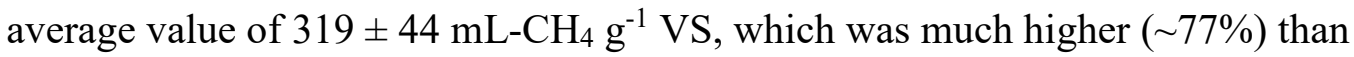

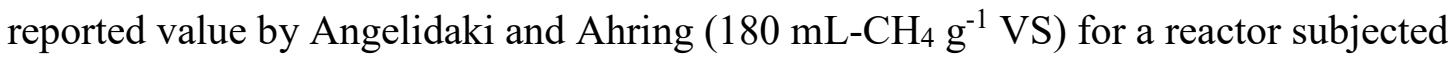
to the same level of ammonia concentration [49]. The average methane yield of the reactor for this period was $6 \%$ and $39.3 \%$ higher than that of glucose addition (39-68 days) and start-up periods (0-39 days), respectively. This is due to decrease of feed flow rate dictated by controller leading to increase of the average HRT of the reactor to 11.5 days, which gives larger time to the bacteria for degrading fibers compared to the period where only glucose was added to the manure. The results indicate that supervisory controller could keep the reactor stable in spite of high ammonia $\left(6 \mathrm{~g}-\mathrm{N} \mathrm{L}^{-1}\right)$ and high organic loads (6\% VS).

\subsection{Underload step}

On day 94 (point C in Figs. 4 and 5), addition of glucose and ammonium chloride was stopped (decrease in organic content for the feedstock) and the reactor was fed again with manure with $2 \%$ VS. Immediately after this feedstock change, the methane flow rate and total VFA concentration decreased considerably as a result of organic underload and lack of inhibitors in the feedstock. To control the system, the rules no. 11 
and 12 were active in supervisory controller to maximize the methane production when decreasing the influent VS levels. The controller restored the system to the operational condition similar to the end of start-up period and increased the feed flow rate (Fig. 4d) to its maximum value resulting on an OLR of $4.028 \mathrm{gr} \mathrm{VS} \mathrm{L}^{-1}$ day ${ }^{-1}$ (Fig. 5a) without accumulating VFA. This is a major improvement compared to the control strategy proposed by Boe and Angelidaki [52], which did not distinguish between process inhibition and substrate dilution. The methane production rate was almost constant

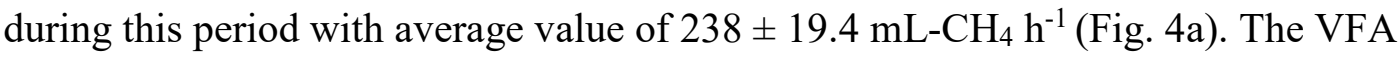
level decreased to $0.25 \mathrm{~g} \mathrm{~L}^{-1}$ by the end of this period (Fig. 4b). The average methane percentage from day 94 to 110 was $68.68 \% \pm 0.63$ (Fig. 5c) which was almost the same as its value before adding glucose $(69.70 \% \pm 1.64)$. As can be seen from Fig. $5 b$, the

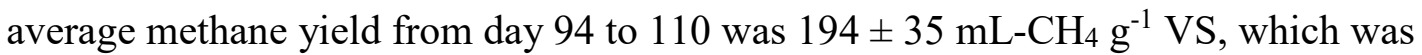

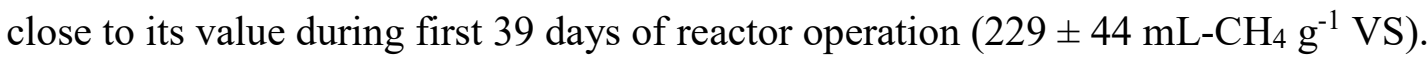
The average HRT of the CSTR under steady state condition was $5 \pm 0.0$ days during this feedstock change (Fig. 5d). The VS reduction from day 94 to 110 was $7.4 \%$. This result indicated that there was a significant residual methane potential still available in the solids fractions (mostly fibers) of manure digested under thermophilic conditions. This result was confirmed by the methane production from the digestate during the batch assays, (Table. S3, Supplementary material). Hence, it is concluded that hydrolysis was the rate limiting step.

\subsection{Change from manure to bio-pulp}

On day 110 (point D in Figs. 4 and 5), the feedstock was changed to bio-pulp and VS was increased from $2 \%$ to $6 \%$. This feedstock change was very similar to the feedstock changes at real biogas plants. At first, methane production instantly boosted due to the 
higher biodegradability of bio-pulp compared to manure [53], (Fig. 4a). The day after bio-pulp addition, rule no. 11 tried to keep the set-point constant as total VFA was increasing and methane flow rate was below previous set-point. After one day, the OLR quickly increased to $8.97 \mathrm{gr} \mathrm{VS} \mathrm{L}^{-1}$ day $^{-1}$ (Fig. 5a). As bio-pulp addition caused increase in methane production rate and total VFA, the supervisory controller increased set-point via rule no. 1 for 2 days while total VFA were below $2 \mathrm{~g} \mathrm{~L}^{-1}$. Since acidogens and acetogens are faster than methanogens [38], the total VFA quickly increased after biopulp addition and subsequently caused decrease in $\mathrm{pH}$. After 3 days, the methane production rate started to decrease due to the methanogens inhibition, while VFA continuously increased above $2 \mathrm{~g} \mathrm{~L}^{-1}$. Thus the supervisory controller started to decrease gas set-point and feed flow rate (Figs. $4 \mathrm{a}$ and 4d, respectively) based on rules no. 4 to 9 (inhibition rules, Table 3). Methane production rate strongly decreased down to $33 \mathrm{~mL}$ $\mathrm{CH}_{4} \mathrm{hr}^{-1}$ and methane percentage reduced down to $36.82 \%$ on day 117 . The average methane percentage was $44.28 \pm 6.28 \%$ during this period (Fig. 5 c). After 8 days, the total VFA increased up to $10.12 \mathrm{~g} \mathrm{~L}^{-1}$ (Fig. 4b) and $\mathrm{pH}$ dropped to 5.6 (Fig. 4c). The controller could not reject the disturbance, which led to process failure. The inter-lock system was activated and stopped the reactor feeding (Fig. 4d) as pH fell below 6 . In order to improve the performance of the rule based controller, one rule was added to the proposed rules. As can be seen from Fig. 4d, between days 94 and 110 the feed flow rate was at maximum value (input saturation) and the methane production rate was almost constant (Fig. 4a). This means that the reactor was working at its maximum capacity. Following rule no.12 (Table 3), the controller had increased the set-point during this period, while increasing the methane production was infeasible as the feed flow rate was at its maximum. This strategy resulted in a large tracking error at the end 
of this period, when feed switching (manure to bio-pulp) was applied. This high value of the tracking error before feed switching time, resulted in reactor instability due to rapid increase of total VFA concentration. To avoid such a phenomenon a new rule for feed flow rate saturation $\left(13^{\text {th }}\right.$ rule in Table. 3$)$ was added.

On day 121 (point E in Figs. 4 and 5), the feedstock was changed to manure (2\% VS). Immediately after manure addition, accumulated VFAs were converted to biogas (due to the $\mathrm{pH}$ regulation because of high buffer capacity of manure). As methane flow rate was increasing, the supervisory controller started to increase gas set-point and feed flow rate with activation of rules no. 1 and 2. After 8 days, the digester returned to the similar stable condition before adding the bio-pulp. The total VFA concentration decreased down to $0.31 \mathrm{~g} \mathrm{~L}^{-1}$ on day 143 , and subsequently $\mathrm{pH}$ increased up to 7.78 . The average methane composition in biogas increased up to $65.49 \% \pm 9.73$ during days 121 to 145 . HRT decreased down to 5 days by the end of this operation time (Fig. $5 \mathrm{~d}$ ). It should be noted that during days 129 to 145 , the feed flow rate had been saturated several times leading to activation of rule no. 13 and preventing the increase of the gas set-point. Utilizing the new rule led to smaller tracking error on day 145 when the feedstock was changed to bio-pulp. On day 145 (point F in Figs. 4 and 5), the same feedstock change (bio-pulp, 6\% VS) was introduced to the digester. Methane flow rate (Fig. 4a) and methane yield (Fig. 5b) immediately increased up to $2343 \mathrm{~mL}_{-} \mathrm{CH}_{4} \mathrm{~h}^{-1}$ and $846 \mathrm{~mL}-$ $\mathrm{CH}_{4} \mathrm{~g}^{-1} \mathrm{VS}$, respectively, due to the 3 times increase of VS content (from $2 \%$ to $6 \% \mathrm{VS}$ ) and the higher biodegradability of bio-pulp compared to manure $[53,54]$. The total VFA concentration (Fig. 4b) started to accumulate in the digester since acidogens are faster than methanogens [38]. After 3 days (e.g. on day 148), the total VFA concentration went above $2 \mathrm{~g} \mathrm{~L}^{-1}$ and supervisory controller started to decrease methane production 
set-point and hence the feed flow rate via activation of rules no. 4 to 9 (inhibition rules, Table 3) depending on the VFA levels. The controller prevented VFA accumulation above $4.09 \mathrm{~g} \mathrm{~L}^{-1}$ (day 149, Fig. 4d), and thus $\mathrm{pH}$ dropped only to 7.49 (Fig. 4c). 6 days after feedstock change, controller restored the VFA concentration below $2 \mathrm{~g} \mathrm{~L}^{-1}$ as before bio-pulp addition (Fig. 4b). After disturbance rejection, from day 150, the supervisory controller started to increase set-point and thus the feed flow rate via rules no. 1,2 and 12 as the digester could manage more OLR while being stable. However, due to oscillation in methane production rate for some periods during operation, rules no. 3 and 11 also became active during this period resulting in constant set-points. Biogas production progressively increased as a consequence of increase in OLR and methanogens growth. The average methane yield was $554 \pm 105 \mathrm{~mL}^{-\mathrm{CH}_{4} \mathrm{~g}^{-1} \mathrm{VS}}$ between days 145 and 170, which was much higher (46\%) than that reported by Tsapekos et al. (380 mL-CH4 $\mathrm{g}^{-1} \mathrm{VS}$ ) [55] from a digester run under thermophilic conditions. Therefore high methane yield could be achieved by using the supervisory control strategy proposed in this work. The high yield of methane production during CSTR operation confirmed that methanogens were active and the reactor performance with bio-pulp was improved compared to the case using manure as feedstock. This is due to the fact that hydrolysis is not the rate limiting step for bio-pulp as a feedstock. 12 days after adding bio-pulp, the OLR reached to the maximum value of $12.08 \mathrm{~g} \mathrm{VS} \mathrm{L}^{-1}$ day $^{-1}$ (Fig. 5a) and the system was working at minimum HRT of 5 days (Fig. 5d) without process imbalance. Liu et al. [56] investigated the effect of different OLR on AD of food waste under thermophilic condition. They showed that the maximum OLR for stable methane production of food waste was $7.5 \mathrm{~g} \mathrm{VS} \mathrm{L}^{-1}$ day $^{-1}$ (with methane yield of $401 \mathrm{~mL}-\mathrm{CH} 4 \mathrm{~g}^{-1} \mathrm{VS}$ ), while in this work it was $12.08 \mathrm{~g} \mathrm{VS} \mathrm{L}^{-1}$ day $^{-1}$ (with methane 
yield of $554 \mathrm{~mL}-\mathrm{CH} 4 \mathrm{~g}^{-1} \mathrm{VS}$ ) without VFA accumulation. The average methane percentage from day 145 to 170 was $63.70 \% \pm 4.53$ (Fig. 5c) which was in accordance with methane percentage in biogas reported for an efficient AD process (methane (50$70 \%)$ ) [1]. The VS reduction during this period was $47.25 \%$.

In order to investigate the maximum methane yield of bio-pulp, a batch experiment as control test was conducted for 25 days. The cumulative methane yield using $6 \%$ VS bio-

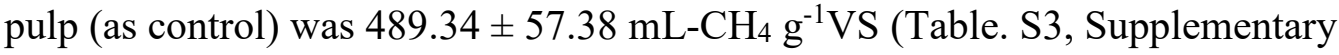
material) in batch experiments (during 25 days) which was below the observed yield in the CSTR. This value was in the same range reported in the literature for batch digestion of bio-pulp under thermophilic condition, $469 \mathrm{~mL}-\mathrm{CH}_{4} \mathrm{~g}^{-1} \mathrm{VS}$ [21], $464 \pm 69$ mL-CH $\mathrm{g} \mathrm{g}^{-1} \mathrm{VS}[22]$ and $549 \pm 9 \mathrm{~mL}^{-\mathrm{CH}_{4}} \mathrm{~g}^{-1} \mathrm{VS}$ [55]. Bio-pulp has higher methane productivity in comparison with cattle manure: a) high biodegradable organic matters (i.e. lipid, protein) and negligible lignocellulosic fibres content; b) pulping process prior to anaerobic digestion in order to boost anaerobic biodegradability [21].

The obtained results indicated that the controller could control the digester and prevent process failure in case of changing feedstock type and organic overload simultaneously (manure, 2\% VS, to bio-pulp, 6\% VS).

\section{Conclusions}

This study demonstrates the application of the supervisory control strategy to improve methane production rate while minimizing the risk of overload or inhibition in an anaerobic digestion process. In the control structure, a feedback control loop was used in inner loop that manipulated the feed flow rate to achieve a gas flow rate set-point. A rule based control was applied in the outer loop that used the gas production rate and the total VFA concentration to decide the changes on the set-point of the inner loop. The 
reactor $\mathrm{pH}$ was measured and if it fell below 6 , the reactor feed flow rate was stopped for the next cycle. When $\mathrm{pH}$ exceeded 6 , the supervisory control system was activated. In order to assess the performance of proposed control strategy, several drastic changes introduced to feedstock as disturbances. The supervisory controller could control the reactor during organic overload (addition of glucose), ammonia inhibition, organic underload and transient from $2 \% \mathrm{VS}$ manure to $6 \% \mathrm{VS}$ bio-pulp. The results indicate that the proposed control strategy was robust against different disturbances.

The experimental results confirmed that the total VFA concentration, as an additional measurement, could improve the performance of the reactor control system especially for systems with high buffer capacity (treating manure).

In this work, the simplest feedback controller, i.e. the proportional controller was used in the inner loop. In order to improve controller performance and eliminate the offset, a proportional-integral (PI) controller can be utilized which is the subject of the future work.

\section{Acknowledgement}

This project was fully supported by Energinet.dk, through the project ForskEL-12197 entitled, Improving synergy and robustness of manure co-digestion process.

\section{References}

[1] Y. Tao, M.E. Ersahin, D.S.M. Ghasimi, H. Ozgun, H. Wang, X. Zhang, M. Guo, Y. Yang, D.C. Stuckey, J.B. van Lier, Biogas productivity of anaerobic digestion process is governed by a core bacterial microbiota, Chem. Eng. J. 380 (2020) 122425. 
[2] C. Mao, Y. Feng, X. Wang, G. Ren, Review on research achievements of biogas from anaerobic digestion, Renew. Sustain. Energy Rev. 45 (2015) 540-555.

[3] V.N. Gunaseelan, Anaerobic digestion of biomass for methane production: a review, Biomass and Bioenergy. 13 (1997) 83-114.

[4] M. Dupla, T. Conte, J.C. Bouvier, N. Bernet, J.-P. Steyer, Dynamic evaluation of a fixed bed anaerobic digestion process in response to organic overloads and toxicant shock loads, Water Sci. Technol. 49 (2004) 61-68.

[5] G. Savoglidis, C. Kravaris, Constant-yield control of continuous bioreactors, Chem. Eng. J. 228 (2013) 1234-1247.

[6] E. Petre, D. Selişteanu, D. Şendrescu, Adaptive and robust-adaptive control strategies for anaerobic wastewater treatment bioprocesses, Chem. Eng. J. 217 (2013) 363-378. doi:10.1016/j.cej.2012.11.129.

[7] J.-P. Steyer, P. Buffière, D. Rolland, R. Moletta, Advanced control of anaerobic digestion processes through disturbances monitoring, Water Res. 33 (1999) 2059-2068.

[8] J. Jimenez, E. Latrille, J. Harmand, A. Robles, J. Ferrer, D. Gaida, C. Wolf, F. Mairet, O. Bernard, V. Alcaraz-Gonzalez, Instrumentation and control of anaerobic digestion processes: a review and some research challenges, Rev. Environ. Sci. Bio/Technology. 14 (2015) 615-648.

[9] D. Nguyen, V. Gadhamshetty, S. Nitayavardhana, S.K. Khanal, Automatic process control in anaerobic digestion technology: A critical review, Bioresour. Technol. 193 (2015) 513-522.

[10] K. Boe, D.J. Batstone, J.-P. Steyer, I. Angelidaki, State indicators for monitoring the anaerobic digestion process, Water Res. 44 (2010) 5973-5980. 
[11] R. Moletta, Y. Escoffier, F. Ehlinger, J.-P. Coudert, J.-P. Leyris, On-line automatic control system for monitoring an anaerobic fluidized-bed reactor: response to organic overload, Water Sci. Technol. 30 (1994) 11-20.

[12] E. Jankowska, A. Duber, J. Chwialkowska, M. Stodolny, P. Oleskowicz-Popiel, Conversion of organic waste into volatile fatty acids-The influence of process operating parameters, Chem. Eng. J. 345 (2018) 395-403.

[13] L. Björnsson, M. Murto, B. Mattiasson, Evaluation of parameters for monitoring an anaerobic co-digestion process, Appl. Microbiol. Biotechnol. 54 (2000) 844849.

[14] B.K. Ahring, M. Sandberg, I. Angelidaki, Volatile fatty acids as indicators of process imbalance in anaerobic digestors, Appl. Microbiol. Biotechnol. 43 (1995) 559-565. doi:10.1007/BF00218466.

[15] F. Molina, M. Castellano, C. García, E. Roca, J.M. Lema, Selection of variables for on-line monitoring, diagnosis, and control of anaerobic digestion processes, Water Sci. Technol. 60 (2009) 615-622.

[16] H.F. Jacobi, C.R. Moschner, E. Hartung, Use of near infrared spectroscopy in monitoring of volatile fatty acids in anaerobic digestion, Water Sci. Technol. 60 (2009) 339-346.

[17] A. Puñal, L. Palazzotto, J.C. Bouvier, T. Conte, J.P. Steyer, Automatic control of volatile fatty acids in anaerobic digestion using a fuzzy logic based approach, Water Sci. Technol. 48 (2003) 103.

[18] J.P. Garcia-Sandoval, H.O. Mendez-Acosta, V. Gonzalez-Alvarez, A. Schaum, J. Alvarez, VFA robust control of an anerobic digestion pilot plant: experimental implementation, IFAC-PapersOnLine. 49 (2016) 973-977. 
[19] K. Boe, J.P. Steyer, I. Angelidaki, Monitoring and control of the biogas process based on propionate concentration using online VFA measurement, Water Sci. Technol. 57 (2008) 661-666. doi:10.2166/wst.2008.046.

[20] K. Boe, I. Angelidaki, Pilot-scale application of an online VFA sensor for monitoring and control of a manure digester, Water Sci. Technol. 66 (2012) 2496-2503. doi:10.2166/wst.2012.498.

[21] I. Naroznova, J. Møller, B. Larsen, C. Scheutz, Evaluation of a new pulping technology for pre-treating source-separated organic household waste prior to anaerobic digestion, Waste Manag. 50 (2016) 65-74.

[22] P. Tsapekos, P.G. Kougias, S. Kuthiala, I. Angelidaki, Co-digestion and model simulations of source separated municipal organic waste with cattle manure under batch and continuously stirred tank reactors, Energy Convers. Manag. 159 (2018) 1-6.

[23] O. Yenigün, B. Demirel, Ammonia inhibition in anaerobic digestion: a review, Process Biochem. 48 (2013) 901-911.

[24] R. Rajagopal, D.I. Massé, G. Singh, A critical review on inhibition of anaerobic digestion process by excess ammonia, Bioresour. Technol. 143 (2013) 632-641.

[25] P.G. Kougias, T.A. Kotsopoulos, G.G. Martzopoulos, Effect of feedstock composition and organic loading rate during the mesophilic co-digestion of olive mill wastewater and swine manure, Renew. Energy. 69 (2014) 202-207.

[26] I. Angelidaki, L. Ellegaard, B.K. Ahring, Compact automated displacement gas metering system for measurement of low gas rates from laboratory fermentors, Biotechnol. Bioeng. 39 (1992) 351-353.

[27] P. Kaparaju, I. Buendia, L. Ellegaard, I. Angelidakia, Effects of mixing on 
methane production during thermophilic anaerobic digestion of manure: lab-scale and pilot-scale studies, Bioresour. Technol. 99 (2008) 4919-4928.

[28] J. Lindmark, E. Thorin, R.B. Fdhila, E. Dahlquist, Effects of mixing on the result of anaerobic digestion, Renew. Sustain. Energy Rev. 40 (2014) 1030-1047.

[29] P. Weiland, Biogas production: current state and perspectives, Appl. Microbiol. Biotechnol. 85 (2010) 849-860.

[30] B. Valverde-Pérez, M. Mauricio-Iglesias, G. Sin, Systematic design of an optimal control system for the SHARON-Anammox process, J. Process Control. 39 (2016) $1-10$.

[31] D.E. Seborg, D.A. Mellichamp, T.F. Edgar, F.J. Doyle III, Process dynamics and control, John Wiley \& Sons, 2010.

[32] I. Angelidaki, K. Boe, L. Ellegaard, Effect of operating conditions and reactor configuration on efficiency of full-scale biogas plants, Water Sci. Technol. 52 (2005) 189-194.

[33] A. Apha, WPCF, Standard methods for the examination of water and wastewater, Am. Public Heal. Assoc. Washington, DC. (1995).

[34] H.-C.H. Lützhøft, K. Boe, C. Fang, I. Angelidaki, Comparison of VFA titration procedures used for monitoring the biogas process, Water Res. 54 (2014) 262272.

[35] B.K. Ahring, A.A. Ibrahim, Z. Mladenovska, Effect of temperature increase from 55 to $65 \mathrm{C}$ on performance and microbial population dynamics of an anaerobic reactor treating cattle manure, Water Res. 35 (2001) 2446-2452.

[36] I.M. Nasir, T.I.M. Ghazi, R. Omar, Anaerobic digestion technology in livestock manure treatment for biogas production: a review, Eng. Life Sci. 12 (2012) 258- 
269.

[37] P. Tsapekos, P.G. Kougias, A. Frison, R. Raga, I. Angelidaki, Improving methane production from digested manure biofibers by mechanical and thermal alkaline pretreatment, Bioresour. Technol. 216 (2016) 545-552.

[38] P.M. Christy, L.R. Gopinath, D. Divya, A review on anaerobic decomposition and enhancement of biogas production through enzymes and microorganisms, Renew. Sustain. Energy Rev. 34 (2014) 167-173.

[39] Y. Wang, Y. Zhang, J. Wang, L. Meng, Effects of volatile fatty acid concentrations on methane yield and methanogenic bacteria, Biomass and Bioenergy. 33 (2009) 848-853.

[40] M. Hannsson, Å. Nordberg, I. Sundh, B. Mathisen, Early warning of disturbances in a laboratory-scale MSW biogas process, Water Sci. Technol. 45 (2002) 255260.

[41] G.E. Symons, A.M. Buswell, The methane fermentation of carbohydrates 1, 2, J. Am. Chem. Soc. 55 (1933) 2028-2036.

[42] T. Liu, S. Sung, Ammonia inhibition on thermophilic aceticlastic methanogens, Water Sci. Technol. 45 (2002) 113-120.

[43] H. Tian, I.A. Fotidis, K. Kissas, I. Angelidaki, Effect of different ammonia sources on aceticlastic and hydrogenotrophic methanogens, Bioresour. Technol. 250 (2018) 390-397.

[44] S. Chen, J. He, H. Wang, B. Dong, N. Li, X. Dai, Microbial responses and metabolic pathways reveal the recovery mechanism of an anaerobic digestion system subjected to progressive inhibition by ammonia, Chem. Eng. J. 350 (2018) 312-323. 
[45] E.J. Kroeker, D.D. Schulte, A.B. Sparling, H.M. Lapp, Anaerobic treatment process stability, J. (Water Pollut. Control Fed. (1979) 718-727.

[46] L.A. De Baere, M. Devocht, P. Van Assche, W. Verstraete, Influence of high $\mathrm{NaCl}$ and $\mathrm{NH} 4 \mathrm{Cl}$ salt levels on methanogenic associations, Water Res. 18 (1984) $543-548$.

[47] S. Sung, T. Liu, Ammonia inhibition on thermophilic anaerobic digestion, Chemosphere. 53 (2003) 43-52.

[48] C. Gallert, J. Winter, Mesophilic and thermophilic anaerobic digestion of sourcesorted organic wastes: effect of ammonia on glucose degradation and methane production, Appl. Microbiol. Biotechnol. 48 (1997) 405-410.

[49] I. Angelidaki, B.K. Ahring, Anaerobic thermophilic digestion of manure at different ammonia loads: effect of temperature, Water Res. 28 (1994) 727-731.

[50] I. Angelidaki, B.K. Ahring, Thermophilic anaerobic digestion of livestock waste: the effect of ammonia, Appl. Microbiol. Biotechnol. 38 (1993) 560-564.

[51] I. Angelidaki, L. Ellegaard, B.K. Ahring, A mathematical model for dynamic simulation of anaerobic digestion of complex substrates: focusing on ammonia inhibition, Biotechnol. Bioeng. 42 (1993) 159-166.

[52] K. Boe, I. Angelidaki, Pilot-scale application of an online VFA sensor for monitoring and control of a manure Boe, K., Angelidaki, I., 2012. Pilot-scale application of an online VFA sensor for monitoring and control of a manure digester. Water Sci. Technol. 66, 2496-2503.digest, Water Sci. Technol. 66 (2012) 2496-2503.

[53] J. Fernández-Rodríguez, M. Pérez, L.I. Romero, Comparison of mesophilic and thermophilic dry anaerobic digestion of OFMSW: Kinetic analysis, Chem. Eng. 
J. 232 (2013) 59-64.

[54] L. Appels, J. Lauwers, J. Degrève, L. Helsen, B. Lievens, K. Willems, J. Van Impe, R. Dewil, Anaerobic digestion in global bio-energy production: potential and research challenges, Renew. Sustain. Energy Rev. 15 (2011) 4295-4301.

[55] P. Tsapekos, M. Alvarado-Morales, P.G. Kougias, K. Konstantopoulos, I. Angelidaki, Co-digestion of municipal waste biopulp with marine macroalgae focusing on sodium inhibition, Energy Convers. Manag. 180 (2019) 931-937.

[56] C. Liu, W. Wang, N. Anwar, Z. Ma, G. Liu, R. Zhang, Effect of organic loading rate on anaerobic digestion of food waste under mesophilic and thermophilic conditions, Energy \& Fuels. 31 (2017) 2976-2984. 


\section{Supplementary material}

\section{S1. Comparison between GC and titration method for total VFA concentration}

The total VFA concentration was measured using two $\mathrm{pH}$ end-points titration method [34] during reactor operation. The total VFA concentration was also measured with GC in order to validate the data derived from titration technique. As it is shown in Fig. S1 $(\mathrm{a}, \mathrm{b})$, total VFA concentrations calculated using titration method were close to the GC values with a good accuracy $\left(\mathrm{R}^{2}=0.98\right)$. This results confirmed the accuracy of titration method in calculating the total VFA concentration.
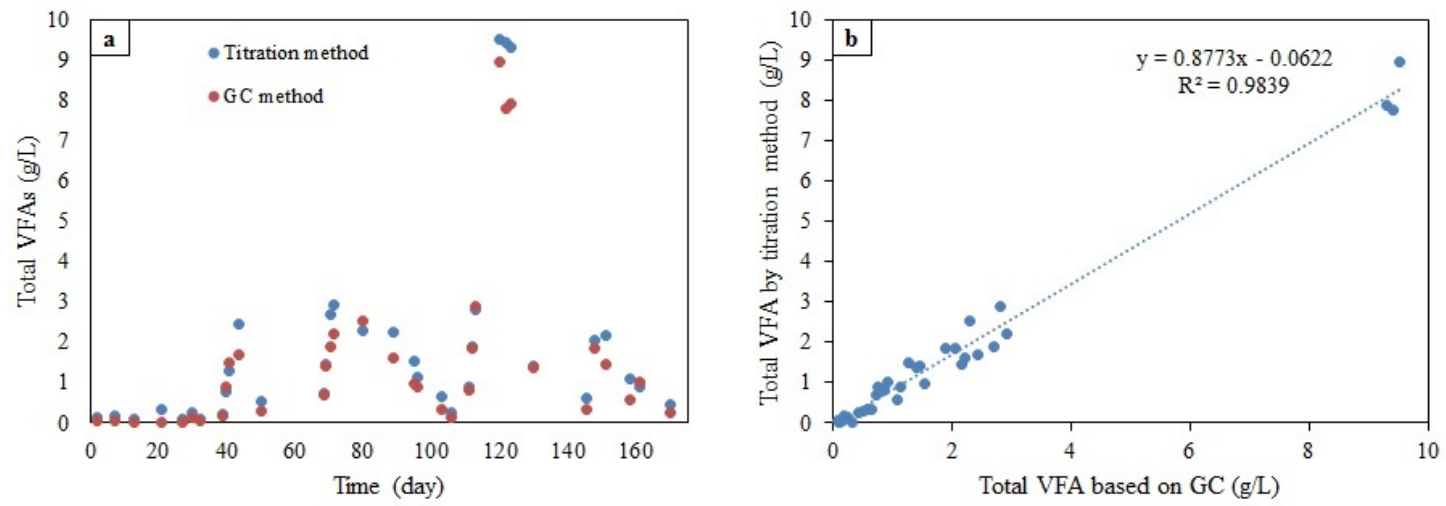

Figure S1. a) Total VFA concentration during reactor operation based on GC method and titration method, b) Total VFA concentration based on titration vs GC method.

\section{S2. Individual VFAs concentration based on GC method}

Concentration of each individual VFA was measured using GC before and after each feedstock changes and during steady state condition.

As can be seen from Fig. S2, generally concentrations of acetate and propionate are dominant in the total VFA concentration. 


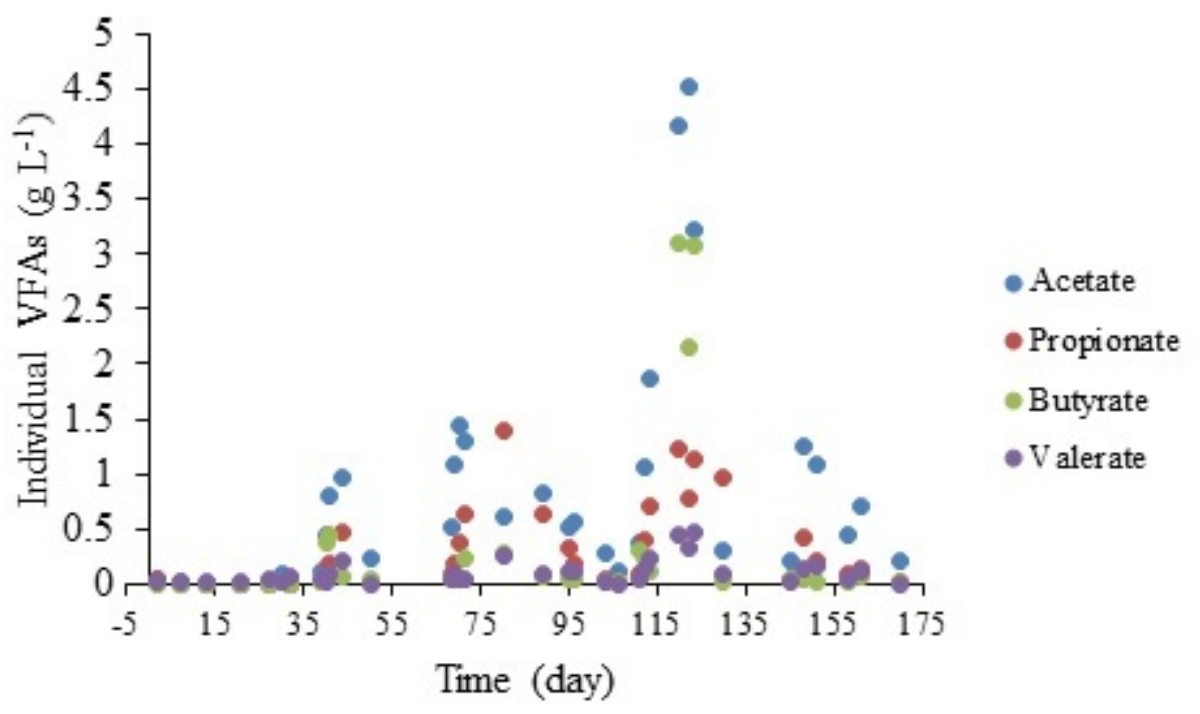

Figure S2. Individual VFAs concentration during reactor operation

\section{S3. Bio-methane potential results}

The Bio-methane potential of cattle manure (2\% VS) and bio-pulp ( $6 \% \mathrm{VS})$ as basic substrates of the digester and reactor effluents during batch experiments ( 25 days) is given in Table. S3.

Table S3. Bio-methane potential (BMP) of different batch assays (feedstocks and effluent samples)

\begin{tabular}{|l|c|}
\hline \multicolumn{1}{|c|}{ Samples } & $\begin{array}{c}\text { Bio-methane yield } \\
\left.\text { (mL-CH4 } \mathbf{~ g}^{-1} \text { VS }\right)\end{array}$ \\
\hline Feedstock : Manure (2\%VS) & 256.9508 \\
\hline Feedstock : Bio-pulp (6\%VS) & 489.34253 \\
\hline Effluent: Manure, (2\% VS) (start-up) & 184.0519 \\
\hline Effluent: Manure + Glucose, (6\% VS) (overload condition) & 167.5537 \\
\hline Effluent: Manure + Glucose + $\mathrm{NH}_{4} \mathrm{Cl}$, (6\% VS) (ammonia inhibition) & 154.7541 \\
\hline Effluent: Manure, (2\% VS) (organic underload condition) & 132.8248 \\
\hline Effluent: Manure, (2\% VS) (after first bio-pulp addition) & 248.589 \\
\hline Effluent: Bio-pulp (6\% VS) (bio-pulp addition) & 170.1592 \\
\hline
\end{tabular}

